\title{
Upaya Memutus Rantai Infeksi dengan Hand Hygiene
}

Fitri Rahman Batubara

Fitri.batubara.fr@gmai.com

\begin{abstract}
Abstrak
Penyakit infeksi masih merupakan salah satu masalah kesehatan di dunia, termasuk Indonesia. Mencegah atau membatasi penularan infeksi di sarana pelayanan kesehatan memerlukan penerapan prosedur dan protokol yang disebut sebagai "pengendalian". Perawat berperan penting sebagai pemutus rantai infeksi untuk menurunkan angka kejadian infeksi yang didapat di rumah sakit (HAIs). Hand hygiene adalah istilah yang digunakan untuk mencuci tangan. Pada tahun (2009), Worrld Health Organization (WHO) mencetuskan global patient safety challage dengan clean care is safe care, yaitu merumuskan inovasi strategi penerapan hand hygiene, yaitu untuk petugas kesehatan dengan my five moment for hygiene, yaitu melakukan cuci tangan sebelum bersentuhan dengan pasien, sebelum melakukan prosedur bersih dan steril, setelah bersentuhan dengan cairan tubuh pasien, setellah bersentuhan atau kontak dengan pasien, setelah bersentuhan dengan lingkungan sekitar pasien.
\end{abstract}

Kata Kunci : Memutus Rantai Infeksi, Hand Hygiene 
1. Latar Belakang

Perawat merupakan tenaga

kesehatan yang berhubungan langsung dengan pasien dan dapat menjadi media transmisi infeksi baik bagi perawat maupun pasien. Perawat mencegah terjadinya infeksi dengan cara memutuskan rantai penularan infeksi. Kegiatan ini berkai- tan dengan perilaku perawat. Perilaku perawat Perawat merupakan tena- ga kesehatan yang berhubungan langsung dengan pasien dan dapat menjadi media transmisi infeksi baik bagi perawat maupun pasien. Perawat mencegah terjadinya infeksi dengan cara memutuskan rantai penularan infeksi. Kegiatan ini berkaitan dengan perilaku perawat. Upaya pencegahan yang dilakukan untuk menjaga keselamatan pasien, salah satunya dengan menerapkan standar operasional prosedur dalam setiap tindakan yang dilakukan tenaga medis di rumah sakit. Pencegahan merupakan aspek kesehatan yang sangat penting untuk memutus rantai penularan suatu penyakit. Pelaksanaan pencegahan infeksi di rumah sakit belum dilakukan dengan benar karena masih terdapat beberapa item pencegahan yang tidak dilakukan antara lain audit kepatuhan hand hygiene secara menyeluruh dari uji kompetensi hand hygiene petugas kesehatan. Kebersihan tangan dan kompetensi tenaga kesehatan merupakan dua hal yang penting untuk mencegah terjadinya BSI pada pasien hemodialisis. Tangan dari petugas kesehatan adalah pembawa mikroorganisme paling umum dari satu pasien ke pasien lain dan dari lingkungan yang tercemar kepada pasien. Kebersihan tangan penting dalam tindakan pencegahan karena lebih efektif dan biaya rendah, diperkirakan dengan melaksanakan kebersihan tangan dapat mengurangi terjadinya HAIs. Terdapat lima momen atau lima waktu wajib hand hygiene yaitu: 1) sebelum kontak dengan pasien, 2) sebelum tindakan aseptis, 3) setelah tindakan aseptis, 4) setelah kontak dengan pasien, dan 5) setelah meninggalkan lingkungan pasien. Mencuci tangan adalah membersihkan tangan dari kotoran, mulai dari ujung jari hingga siku dan lengan atas dengan cara tertentu sesui kebutuhan. Mencuci tangan mencegah terjadinya infeksi silang melalui tangan dan menjaga kebersihan individual. Adapun 
variasi mencuci tangan adalah dengan mencuci tangan bersih dan mencuci tangan steril. Hand hygiene adalah aspek yang paling penting untuk mencegah transmisi mikrobakteri patogen dan mencegah infeksi nosokomial. Cuci tangan telah dianggap sebagai salah satu tindakan terpenting untuk mengurangi penularan mikroorganisme dan mencegah infeksi selama lebih dari 150 tahun. Pada tahun 2009 WHO merumuskan strategi penerapan 5 momen 6 langkah untuk petugas kesehatan.

\section{Metode}

Metode yang digunakan dalam kajian ini adalah metode kulaitatif yang bersifat deskriptif mengenai upaya memutus rantai infeksi dengan upaya hand hyegiene demi kenyamanan dalam bekerja. Metode ini berusaha menjelaskan, mengumpulkan, dan menginterpretasikan data yang dilanjutkan dengan faktor-faktor yang berhubungan dengan situasi dan kondisi yang terjadi. Teknik pengumpulan data yang digunakan oleh penulis adalah teknik studi kepustakaan (Library research) menggunakan referensi yang tersedia baik data dari jurnal,
Ejournal, dan Google Schoolar, hingga penelitian sebelumnya yang bertema upaya memutus rantai infeksi dan hand hygiene, yaitu menelusuri literature yang ada dengan membaca serta menganalisisnya dengan memanfaatkan buku, dan jurnal.

\section{Hasil}

Dari hasil review berbagai sumber di dapatkan hasil bahwa perawat merupakan tenaga kesehatan yang berhubungan langsung dengan pasien dan dapat menjadi media transmisi infeksi baik bagi perawat maupun pasien. Perawat mencegah terjadinya infeksi dengan cara memutuskan rantai penularan infeksi. Kegiatan ini berkaitan dengan perilaku perawat dalam melakukan kegiatan pencegahan dan pengendalian infeksi dapat dibentuk dengan aktivitas dalam menampilkan peran dan fungsi kepala ruang sebagai pemimpin. Kepemimpinan kepala ruang dapat memengaruhi peri- laku bawahannya. Manajemen kepala ruang sangat penting dalam menunjang program pencegahan dan pengen- dalian infeksi di rumah sakit. Salah satu fungsi manajemen adalah 
pengorganisasian, dimana kepala ruang hendaknya mengembangkan organisasi keperawatan secara objektif sehingga memudahkan perawat dalam melaksanakan asuhan keperawatan khususnya upaya pencegahan dan pengendalian infeksi. Perilaku perawat dapat ditunjukkan dengan peningkatan kinerja dan kepatuhan perawat dalam melakukan kegiatan pencegahan dan pengendalian infeksi. Tenaga kesehatan yang paling sering melakukan tindakan terhadap pasien di ruang penyakit dalam adalah dokter, perawat dan mahasiswa praktik. Hampir setiap bulan ada mahasiswa praktik sehingga peneliti menjadikan petugas kesehatan baik dokter, perawat maupun mahasiswa praktik dijadikan subjek untuk penelitian ini karena pelaksanaan hand hygiene dengan handwash dan handrub dalam five moments oleh petugas kesehatan harus dilaksanakan. Hand hyegiene dengan menggunakan handwash maupun handrub tekniknya sama saja yaitu dengan enam langkah, waktu pelaksanaannya juga sama yaitu dengan five moments, yang membedakan hanyalah pada medianya, yaitu dimana pada handwash menggunakan sabun dan air mengalir, sedangkan handrub dengan media antiseptik berbasis alkohol. Hasil studi pendahuluan ada perawat yang belum melakukan cuci tangan sesuai prosedur yang ditetapkan RS. Perawat memiliki andil yang sangat besar terhadap terjadinya infeksi nosokomial karena perawat merupakan tenaga kesehatan yang paling banyak melakukan kontak dengan pasien dan berinteraksi secara langsung dengan pasien selama 24 jam. Hasil penelitian kepatuhan petugas di rawat inap lebih rendah dibandingkan dengan bagian lain. Penelitian ini dilakukan untuk mengkaji tingkat kepatuhan perawat di ruang rawat inap RS dalam penerapan hand hygiene, serta faktor apa yang mempengaruhinya.

\section{Pembahasan}

Infeksi merupakan invasi tubuh oleh patogen atau mikroorganisme yang mampu menyebabkan sakit. Infeksi juga disebut asimptomatik apabila mikroorganisme gagal dan menyebabkan cedera yang serius terhadap sel atau jaringan. Penyakit akan timbul jika patogen berkembang biak dan menyebabakan perubahan 
pada jaringan normal. Infeksi terjadi secara progresif dan beratnya infeksi pada klien tergantung dari tingkat infeksi, patogenesitas mikroorganisme dan kerentanan penjamu. Dengan proses perawatan yang tepat, maka akan meminimalisir penyebaran dan meminimalkan penyakit. Perkembangan infeksi mempengaruhi tingkat asuhan keperawatan yang diberikan. Secara umum proses atau tahap infeksi adalah sebagai berikut:

- 1. Tahap Inkubasi adalah waktu yang diperlukan darisaat masuknya patogen (penyebab penyakit) kedalam tubuah sampai mulai menimbulkan gejala pertamakali.

- 2. Tahap Prodomal adalah Interval dari awitan tanda dan gejala non spesifik (malaise, demam ringan, keletihan) sampai gejala yang spesifik. Selama masa ini, mikroorganisme tumbuh dan berkembang biak dan klien lebih mampu menyebarkan penyakit ke orang lain

- 3. Tahap Sakit klien adalah memanifestasikan tanda dan gejala yang speifik terhadap jenis sakit
- Tahap Pemulihan adalah interval saat munculnya gejala akut infeksi

Proses rantai penularan infeksi yakni, a) agen/penyebab infeksi, mikroorganisme yang termasuk dalam agen infeksi antara lain bakteri, virus, jamur dan protozoa. Organisme ini siap ditularkan kecuali dengan cuci tangan. Organisme residen tidak dengan mudah bisa dihilangkan melalui cuci tangan dengan sabun dan detergen biasa kecuali bila gosokan dilakukan dengan seksama. Mikroorganisme dapat menyebabkan infeksi tergantung pada: jumlah mikroorganisme, virulensi (kemampuan menyebabkan penyakit), kemampuan untuk masuk dan bertahan hidup dalam host serta kerentanan dalam host/pejamu. b) Reservoir (sumber mikroorganisme) adalah tempat dimana mikroorganisme patogen dapat hidup baik berkembang biak atau tidak adalah manusia, binatang, makanan, air, serangga dan benda lain. Kebanyakan reservoir adalah tubuh manusia, terutama dikulit, mukosa, cairan atau drainase. Adanya mikroorganisme patogen dalam tubuh tidak selalu menyebabkan penyakit pada hostnya. Sehingga reservoir yang didalamnya terdapat mikroorganisme patogen bisa menyebabkan orang lain bisa menjadi sakit (carier). Kuman 
dapat hidup dan berkembang biak dalam reservoir jika karakteristik reservoirnya cocok dengan kuman. Karakteristik tersebut adalah air, suhu, ph, udara dan pencahayaan. c) Portal of exit (jalan keluar), mikroorganisme yang hidup didalam reservoir harus menemukan jalan keluar untuk masuk ke dalam host dan menyebabkan infeksi. Sebelum menimbulkan infeksi, mikroorganisme harus keluar terlebih dahulu dari reservoirnya. Jika reservoirnya manusia, kuman dapat keluar melalui saluran pencernaan, pernafasan, perkemihan, genetalia, kulit, membrane mukosa yang rusak serta darah. d) Cara penularan (transmisi) bisa secara direct/Langsung : kontak badan ke badan transfer kuman penyebab secara fisik pada saat pemeriksaan fisik, memandikan klien, dll, dan Indirect/Tidak langsung: kontak melalui objek (benda/alat). Dengan perantara: instrumen, jarum, kasa, tangan yang tidak dicuci.

Maka dari itu, Hand hygiene adalah istilah yang digunakan untuk mencuci tangan menggunakan antiseptik pencuci tangan 6 langkah. Pada tahun 2009, WHO mencetuskan global patient safety challenge dengan clean care is safe care, yaitu merumuskan inovasi strategi penerapan hand hygiene untuk petugas kesehatan dengan my five moment for hand hygiene adalah melakukan cuci tangan, sebelum bersentuhan dengan pasien, sebelum melakukan prosedur bersih/steril, setelah bersentuhan dengan pasien, setelah bersentuhan dengan cairan tubuh pasien, setelah bersentuhan dengan lingkungan sekitar pasien. (WHO 2009) sebuah penelitian pada 40 rumah sakit melaporkan kepatuhan tenaga kesehatan yang melakukan hand hygiene sebelum dan setelah pasien bervariasi antara $24 \%$ sampai $89 \%$ (rata-rata 56,6\%). Penelitian ini dilakukan setelah dipromosikannya program WHO dalam pengendalian infeksi seperti tersebut diatas.

Kesadaran cuci tangan (hand hygiene) pada petugas kesehatan merupakan perilaku yang mendasar dalam upaya mencegah infeksi silang. Cuci tangan mempunyai pengaruh besar terhadap pencegahan terjadinya infeksi nosokomial di rumah sakit dan perawat mempunyai andil besar karena berinteraksi dengan pasien selama 24 jam. Mencuci tangan adalah salah satu tindakan sanitasi dengan membersikan jari-jemari menggunakan air atau pun cairan lainnya oleh manusia dengan tujuan untuk menjadi bersih, sebagai ritual keagamaan, ataupun tujuantujuan lainnya. Antiseptik merupakan bahan kimia untuk mencegah multiplikasi 
mikroorganisme pada permukaan tubuh, dengan cara membunuh mikroorganisme tersebut atau menghambat pertumbuhan dan aktivitas metaboliknya. Hand sanitizer antiseptik yang sering digunakan adalah alkohol. Alkohol telah digunakan secara luas sebagai obat antiseptik kulit karena mempunyai efek menghambat pertumbuhan bakteri Mencuci tangan adalah membersihkan tangan dari kotoran, mulai dari ujung jari hingga siku dan lengan atas dengan cara tertentu sesui kebutuhan. Mencuci tangan mencegah terjadinya infeksi silang melalui tangan dan menjaga kebersihan individual. Adapun variasi mencuci tangan adalah dengan mencuci tangan bersih dan mencuci tangan steril. Mencuci tangan adalah salah satu tindakan sanitasi dengan membersikan jari-jemari menggunakan air atau pun cairan lainnya oleh manusia dengan tujuan untuk menjadi bersih, sebagai ritual keagamaan, ataupun tujuantujuan lainnya. Antiseptik merupakan bahan kimia untuk mencegah multiplikasi mikroorganisme pada permukaan tubuh, dengan cara membunuh mikroorganisme tersebut atau menghambat pertumbuhan dan aktivitas metaboliknya. Hand sanitizer antiseptik yang sering digunakan adalah alkohol. Alkohol telah digunakan secara luas sebagai obat antiseptik kulit karena mempunyai efek menghambat pertumbuhan bakteri. Penelitian ini bertujuan untuk mengetahui efektivitas mencuci tangan menggunakan cairan pembersih tangan antiseptik (hand sanitizer) terhadap jumlah angka kuman.

Selain mencuci tangan ada juga beberapa rinsip pencegahan infeksi antara lain :

- Antiseptik, adalah usaha mencegah infeksi dengan cara membunuh atau menghambat pertumbuhan mikroorganisme pada kulit atau jaringan tubuh lainnya.

- Aseptik, adalah semua usaha yang dilakukan dalam mencegah masuknya mikroorganisme ke dalam tubuh yang mungkin akan menyebabkan infeksi. Tujuannya adalah mengurangi atau menghilangkan jumlah mikroorganisme, baik pada permukaan benda hidup maupun benda mati agar alat-alat kesehatan dapat digunakan dengan aman.

- Dekontaminasi, adalah tindakan yang dilakukan untuk memastikan bahwa petugas kesehatan dapat menangani secara aman bendabenda (peralatan medis, sarung tangan, meja pemeriksaan) yang terkontaminasi darah dan cairan tubuh. Cara memastikannya adalah segera melakukan dekontaminasi terhadap benda - benda tersebut 
setelah terpapar/terkontaminasi

darah atau cairan tubuh

- Desinfeksi, adalah tindakan yang tindakan menghilangkan sebagian besar mikroorganisme penyebab penyakit dari benda mati.

- Desinfeksi Tingkat Tinggi (DTT), ialah suatu proses yang menghilangkan mikroorganisme kecuali beberapa endospora bakteri pada benda mati dengan merebus, mengukus, atau penggunaan desinfektan kimia.

- Mencuci dan membilas, yakni suatu proses yang secara fisik menghilangkan semua debu, kotoran, darah, dan bagian tubuh lain yang tampak pada objek mati dan membuang sejumlah besar mikro organisme untuk mengurangi resiko bagi mereka yang menyentuh kulit atau menangani benda tersebut (proses ini terdiri dari pencucian dengan sabun atau deterjen dan air, pembilasan dengan air bersih dan pengeringan secara seksama).

- Sterilisasi adalah tindakan yang dilakukan untuk menghilangkan semua mikroorganisme (bakteri, virus, jamur, parasit), termasuk endospora bakteri pada benda-benda mati atau instrument.

\section{Penutup}

Upaya untuk mencegah kejadian infeksi nosokomial yang penting adalah penerapan standar precaution baik bagi pasien, petugas, lingkungan dan alat kesehatan, dengan tujuan untuk memutuskan rantai penularanya. Dengan mencuci tangan yang merupakan salah satu tindakan sanitasi dengan membersikan jarijemari menggunakan air atau pun cairan lainnya oleh manusia dengan tujuan untuk menjadi bersih, sebagai ritual keagamaan, ataupun tujuan-tujuan lainnya. Antiseptik merupakan bahan kimia untuk mencegah multiplikasi mikroorganisme pada permukaan tubuh, dengan cara membunuh mikroorganisme tersebut atau menghambat pertumbuhan dan aktivitas metaboliknya. Hand sanitizer antiseptik yangtelah digunakan secara luas sebagai obat antiseptik kulit karena mempunyai efek menghambat pertumbuhan bakteri. Penelitian ini bertujuan untuk mengetahui efektivitas mencuci tangan menggunakan cairan pembersih tangan antiseptik (hand sanitizer) terhadap jumlah angka kuman. 


\section{Referensi}

Edisah Putra Ritonga. 2017. Pelaksanaan

Five Moment Hand Hygiene di Ruang

Rawat Inap Rumah Sakit Swasta Kota Medan. Jurnal Ilmiah Keperawatan Imelda, 3 (2).

Elies E., Asih Tri R., Satra W. 2014. Penerapan Hand Hygiene Perawat di Ruang Rawat Inap Rumah Sakit. Jurnal Kedokteran Brawijaya, 28 (1).

Fitriana D., Hanny H., Kuntarti. 2016. Memutus Rantai Infeksi Melalui Fungsi Pengorgarnisasian Kepala Ruang Rawat. Jurnal Keperawatan Indonesia, 19 (2).

Heny N., Apriyani P. H. 2018. Penerappan Model Perilaku Perawat Tentang Hand Hygiene Berbasis Theory Of Planned Behaviour dan Kepatuhan Perawat Melakukan Hand Hygiene 5 Moment 6 Langkah.

Intan P.S., Dhona A., Masra R. 2014. Hubungan Antara Pengetahuan Tentang Infeksi Silang Dengan Penatalaksanaan Pencegahan Infeksi. Jurnal B-Dent, 1 (1).

Max J. H., Rini S. H. 2016. Sarana dan Prasarana Rumah Sakit dalam Upaya Pencegahan dan Pengendalian Infeksi di Indonesia. Jurnal Kefarmasian Indonesia, $6(2)$.
Muhammad Abdurrauf. 2016. Memutus Rantai Penularan Konjungtivitis Bakteri Akut. Idea Nursing Journal, 7 (2).

Novita P. L., Vonny N. S. W., Damajanty H.C. P. 2019. Penceahan dan Pengendalian Infeksi Silang Pada Tindakan Ektraksi Gigi di Poli Gigi Puskesmas Kakaskaken Tomhon. Jurnal e-gigi, 7 (1).

Rudatin W., Ani Fatkhi R. 2017. Analisis Daerah Rawan Air dan Penyakit Berbasis Lingkungan Pada Daerah Padat Penduduk dengan Water Stress Index Calculation. Jurnal Of Health Education, 2 (2).

Shely S., Richa N., Irman S. 2017. Gambaran Pelaksanaan Kegiatan Kebersihan Tangan Oleh Petugas Kesehatan di Rumah Sakit Dustira Cimahi. Jurnal Pendidikan Keperawatan Indonesia, 3 (1).

Simamora, R. H. (2019). Pengaruh Penyuluhan Identifikasi Pasien dengan Menggunakan Media Audiovisual terhadap Pengetahuan Pasien Rawat Inap. Jurnal Keperawatan Silampari, 3(1), 342-351.

Simamora, R. H. (2020). Learning of Patient Identification in Patient Safety Programs Through Clinical Preceptor Models. Medico Legal Update, 20(3), 553-556. 